\title{
Thermal energy use for dehumidification of a tomato greenhouse by natural ventilation and a system with an air-to-air heat exchanger
}

\author{
Katarzyna Maslak and Sven Nimmermark \\ Swedish University of Agricultural Sciences (SLU), Dept. of Biosystems and Technology, \\ P.O. Box 103, SE-230 53 Alnarp, Sweden \\ e-mail: sven.nimmermark@slu.se
}

\begin{abstract}
The aim of the study was to estimate the amount of thermal energy used for dehumidification of a naturally ventilated tomato greenhouse and to estimate how mechanical ventilation with the use of a heat exchanger recovering heat from the exhaust to the supply air may decrease the energy use. Measured use of thermal energy in a naturally ventilated tomato greenhouse was compared to modelled values using Powersim ${ }^{\circledR}$ software. By the help of the model an estimation of the amount of energy used for dehumidification was made for the months April - September. A non-hygroscopic rotary air-to-air heat exchanger was studied, and its temperature and moisture efficiencies were measured. Modelling for leaf area index (LAI) 3.5 and $4.0 \mathrm{~m}^{2} \mathrm{~m}^{-2}$ indicated that 23 and $29 \%$ of the total thermal energy was used for moisture removal respectively. Modelling for the heat exchanger indicated thermal energy savings of 15 and $17 \%$ for the same LAl respectively.
\end{abstract}

Key words: thermal energy use, greenhouses, humidity, dehumidification, ventilation, rotating heat exchanger

\section{Introduction}

Humidity control is highly important for having a high yield in greenhouses and the effects of humidity on production of greenhouse fruit vegetables was thoroughly studied by Bakker (1991). Depending on the plant species, relative humidity (RH) in the range of $60-90 \%$ is desired (Kittas et al. 2012). Both too low and too high values, lasting for a longer time, affect the plants in a negative way. Low humidity levels may lead to water stress which in turn inhibits the plant growth, i.e. reduces the leaf size and stem length (Farooq et al. 2009, Jaleel et al. 2009). Excessive humidity may result in condensation on greenhouse walls, ceiling and floor as well as on plants. For most greenhouse cover materials condensation on the internal greenhouse surfaces reduces the amount of solar radiation reaching the crop. Pollet and Pieters (2000) found a reduced light transmittance of $0-23 \%$ by condensation on some studied cover materials. At high humidity levels in the greenhouse, also condensation on plants may take place and persistent high humidity with values above 95\% may result in fungal diseases (Williamson et al. 1995, Babadoost 2011) which impair the quality of crops and decrease the yield. High humidity also reduces the transpiration of the plants and limits their uptake of nutrients. In order to assure that the level of humidity does not exceed the optimal value, an efficient dehumidifying system is indispensable. Since dehumidification may require large amounts of energy, an evaluation of different systems regarding energy use is interesting.

Several techniques are available for removing excess moisture from the greenhouse air. A common technique is the combination of heating and ventilation, either by natural ventilation or forced by a mechanical device, e.g. a fan or a blower. Heat pumps for dehumidification were studied by Gustafsson and Nimmermark (1991) and Migeon et al. (2012), and a system based on condensation on cooled finned pipes was tested by Campen and Bot (2002). Longo and Gasparella (2012) described a dehumidification system where liquid desiccants (hygroscopic substances) are used. Two other methods, one employing cold water fan coils and another one using cold water curtains, were described by Vallières et al. (2014). For closed or semi-closed greenhouses heat storage is an option, and in a Dutch greenhouse with potted plants a heating/cooling system with water-to-air fine wire heat exchangers consisting of copper capillaries (woven fine tin coated copper wires) was tested for heating, cooling and dehumidification (Bakker et al. 2006).

Campen et al. (2003) compared three alternative dehumidification methods with a conventional dehumidification system based on natural ventilation, i.e. 1) condensation on a cold surface, 2) absorption by a desiccant, and 3) mechanical ventilation with a heat exchanger (air-to-air). Campen et al. (2003) concluded that the method with mechanical ventilation and heat exchange can be competitive. 
Heat exchangers can be classified according to various criteria (Kakaç et al. 2012). The heat exchangers can be either recuperative (e.g. flat plate heat exchangers) or regenerative (e.g. rotary heat exchangers where heat is temporarily stored in the rotating wheel). Further, they can be categorized based on the working media used (e.g. liquid-to-air, air-to-air etc.), the construction (tubular, plate and extended surface), the type of the heat transfer process (direct and indirect contact), and the flow arrangement (counter-flow, parallel-flow and cross-flow).

Counter-flow heat exchangers can have high temperature efficiencies. A prototype of an air-to-air multi-tube counter-flow heat exchanger used for dehumidification of a tomato/cucumber greenhouse located in Canada was studied by Rousse et al. (2000). During March to May the average temperature efficiencies were high (78-84\%) and a significant contribution of latent heat (of up to about 40\%) to the overall heat transfer was found.

Although specially designed heat exchangers and energy conservation methods for dehumidification of greenhouses are interesting, also heat exchange methods and equipment used in conventional air-conditioning systems for other types of buildings are highly interesting since they already exist in the market. In many cases plate heat exchangers are used in such systems. Another option for dehumidification of greenhouses is rotating heat exchangers.

A rotating heat exchanger (energy wheel) enables the transfer of energy, either in the form of sensible heat or in the form of both sensible and latent heat (total energy wheel). Depending on the type of the wheel, moisture can be transmitted between the air streams to various extents through the processes of condensation (condensation/ non-hygroscopic wheels), condensation and sorption (enthalpy/hygroscopic wheels) or solely sorption (sorption wheels). The working principles of rotary heat exchangers, their construction and characteristics are described in a number of studies (Dinglreiter and Mayinger 1999, Abe et al. 2006, Al-Ghamdi 2006, Sparrow et al. 2007). The rotating heat exchangers can have a high efficiency of 70-90\% and a low pressure drop (Mardiana-Idayu and Riffat 2012, Enventus 2014). Simonson and Besant (1999) pointed out that the effectiveness of a rotary heat exchanger varies depending on the values of inlet temperature and humidity. The rotating heat exchangers are characterized by operational reliability. The problem with condensing water which by itself or by frosting may hinder the flow of air in a flat plate heat exchanger should be less of an issue in case of rotary heat exchangers. According to the authors' knowledge and the literature found no studies investigating the performance of rotating heat exchangers under high humidity conditions typical for greenhouses have been made.

The objective of the study was to estimate to what extent a mechanical ventilation system with a non-hygroscopic rotary air-to-air heat exchanger may reduce the use of energy in a greenhouse. In order to do that measured use of thermal energy was compared with values modelled in Powersim ${ }^{\circledR}$ software and the amount of energy required for dehumidification of a tomato greenhouse was determined. The performance of a non-hygroscopic rotary airto-air heat exchanger was experimentally determined and the simulation model was used to estimate thermal energy savings.

\section{Materials and methods}

Thermal energy use in a tomato greenhouse with natural ventilation for dehumidification was measured, and after that modelled using Powersim ${ }^{\circledR}$ software. Tomatoes were planted in the greenhouse in the middle of February. A comparison between measured and modelled data was made and thermal energy use for dehumidification by natural ventilation was estimated from the model output. Subsequently, it was assumed in simulations that mechanical ventilation with a heat exchanger was used to dehumidify the greenhouse. The performance of the heat exchanger was in the modelling based on in situ measurements. The exact methodology used in this study is described below.

\section{Greenhouse facility investigated in the study}

The facility where measurements were performed and for which modelling was made was a tomato greenhouse located in the southern part of Sweden, in the province of Scania. It was a Venlo-type greenhouse consisting of eight equally sized compartments having the total area of $80000 \mathrm{~m}^{2}$. The height of the greenhouse was $5.0 \mathrm{~m}$ to the gutter and the roof inclination angle was $26^{\circ}$. The covering material used for the roof and the walls was single glass. Additionally, the lower part of the walls, up to the height of $1.5 \mathrm{~m}$, was insulated. The southern wall was sprayed with lime up to the height of $3.0 \mathrm{~m}$. Thermal screens were used in each of the compartments. 
K. Maslak \& S. Nimmermark (2017) 26: 56-66

A natural gas boiler was used to provide heat energy to the greenhouse. The water based heating system consisted of two circuits - one serving compartments no. 2, 4, 6 and 8 and another one serving compartments no. 1, 3, 5 and 7. The heating pipes were located at two different levels - below the plant benches and above the canopy.

A Priva ${ }^{\circledR}$ Intégro system (v. 724) was used to control the indoor climate conditions. Priva ${ }^{\circledR}$ sensors monitoring the temperature and $\mathrm{RH}$ were present in all compartments (there were two pairs of sensors in compartments no. $1-$ 6 and four pairs in compartments $7-8)$.

\section{Collected climate data for energy use calculations and modelling}

Data on the outdoor climate parameters (air temperature, $\mathrm{RH}$ and solar radiation), the indoor conditions (air temperature and humidity), the temperature of incoming/outgoing heating water and the flow meter pulses were collected and stored at the interval of one hour. The outdoor temperature was measured by a sensor of the Priva $^{\circledR}$ meteorological station installed on the greenhouse roof. The incoming solar radiation was measured by a Kipp\&Zonen ${ }^{\circledR}$ solarimeter. The values of outdoor RH were obtained from the data sets prepared by the Swedish Meteorological and Hydrological Institute (SMHI). Values of the indoor temperatures and $\mathrm{RH}$ were measured by means of Priva ${ }^{\circledR}$ sensors located in measuring boxes. The temperatures of incoming and outgoing heating water were measured by Pt100 sensors and the flow rate of the heating water was measured by the help of a Hydrometer WP-XKA, model 457 (nominal diameter: $200 \mathrm{~mm}$; pulse rate: 250 pulses liter $^{-1}$ ).

\section{Simulation software}

A model created in the Powersim ${ }^{\circledR}$ software was used for the simulations. The model enables the user to determine both the energy and the humidity balance of the greenhouse. It constitutes an improved version of a previously made model included in the EBBE program (Nilsson 1985). The model incorporated into EBBE was a static model used for energy balance calculations for Swedish greenhouses. As input data, EBBE used the average daily values of temperature and $\mathrm{RH}$ inside and outside the greenhouse as well as daily solar radiation. In case of the new model programmed using Powersim ${ }^{\circledR}$, hourly values are used instead. An overview of the model and its parameters is shown in Figure 1.

\section{Overview of main blocks and parameters in the model}

\begin{tabular}{|l|}
\hline Block 1- Input data \\
Measured hourly values of: \\
- Outdoor climate - temperature, RH, solar radiation \\
- Indoor climate - temperature, RH \\
Building data: \\
- Areas of floor, all separate parts of walls and all separate parts of \\
roofing. \\
- U-values of different cover areas \\
- Angular orientation of all separate wall and roof surfaces (point of \\
the compass, slope) \\
- Longitude and latitude \\
\hline
\end{tabular}

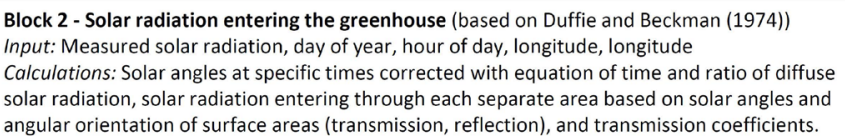

Input: Total and diffuse irradiance, LAl (leaf area index), indoor temperature, indoor humidity, Calculations: Transpiration from irradiance, LAI, indoor temperature and humidity, carbon dioxide concentration (set to $800 \mathrm{ppm}$ ), and constants according to Stranghellini (1987). Output: Transpiration per hour $\left(X_{\text {transp }}, \mathrm{kg}\right)$.

Block 4 - Condensation on walls and ceiling (rough estimation)

input: Indoor temperature and humidity, areas of greenhouse surfaces

Calculations: If indoor humidity $\left(x_{\text {ind }}, \mathrm{kg} / \mathrm{kg}\right)$ is lower than the saturation humidity at a temperature $5^{\circ} \mathrm{C}$ lower temperature than the measured indoor temperature $\left(\mathrm{x}_{\mathrm{sat}}\right.$ ind. temp-5, approx. $75 \% \mathrm{RH}$ at $\left.20-22^{\circ} \mathrm{C}\right)$ no condensation is assumed to occur. Condensation is assumed to be proportional to the area of walls and roof $\left(A_{\text {cover }}\right)$, differens between $x_{\text {ind }}$ and $x_{\text {sat, ind. temp-5 }}(\Delta x)$, and to the ratio $(R)$ between the rate of heat transfer for dry air due to convection -

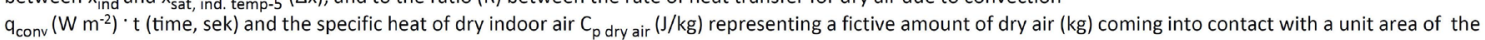
covering material.

Output: Amount of water condensing per hour $\left(\mathrm{X}_{\text {cond }}, \mathrm{kg}\right)$ and corresponding heat loss $\left(\mathrm{P}_{\text {cond }}, \mathrm{kW}\right)$.

Block 5 - Moisture balance

The hourly amount $(\mathrm{kg})$ of water to remove $\left(X_{\text {to remove }}\right)$ by extra ventilation and/or dehumidification is calculated from the hourly values of transpiration of the crop ( $X_{\text {transp, }}$ Block 3$)$, condensation on the covering material $\left(X_{\text {cond, }}, B l o c k 4\right)$ and water removed by infiltration (unwanted ventilation) $\left(X_{\text {unw_vent }}\right)$ according to the equation: $\mathrm{X}_{\text {to remove }}=\mathrm{X}_{\text {transp }}-\mathrm{X}_{\text {cond }}-\mathrm{X}_{\text {unw vent }}$ The ventilation rate $\left(\mathrm{q}_{\text {moist, }}, \mathrm{kg} / \mathrm{h}\right.$ ) needed (including infiltration, $\mathrm{q}_{\text {unw, }} \mathrm{kg} / \mathrm{h}$ ) to remove all excessive moisture is calculated from hourly values $(\mathrm{kg} / \mathrm{h})$ of transpiration of the crop and condensation together with difference between indoor and outdoor humidity $(\Delta x, \mathrm{~kg} / \mathrm{kg})$ according to the equation: $q=\left(x_{\text {transp }}-x_{\text {cond }}\right) / \Delta x$. In cases when $q_{\text {unw }}$ is high enough to remove the moisture $q$ is set to $q_{\text {unw }}$

Output: Amount of water to remove and air flow rate for moisture balance

\section{Block 6 - Heat balance}

Hourly values of supply heat demand $\left(P_{\text {supply }}, \mathrm{kW}\right)$ for calculation of thermal energy use are derived from the heat balance equation:

$P_{\text {supply }}+P_{\text {sun }}=P_{\text {trans }}+P_{\text {vent }}+P_{\text {cond }}$, where $P_{\text {sun }}(\mathrm{kW})$ is incoming heat from the sun (Block 2), $P_{\text {trans }}(\mathrm{kw})$ is heat loss by heat transfer though walls, roof, and floor calculated from U-values and input data of climate and screen positions (Block 1), $P_{\text {vent }}(\mathrm{kW}$ ) is heat losses by ventilation calculated from the ventilation rate to remove moisture $\left(\mathrm{q}_{\text {moist }}\right.$ in Block 5$)$ together with enthalpies $(\mathrm{h}, \mathrm{J} / \mathrm{kg})$ of indoor and outdoor air, and $\mathrm{P}_{\text {cond }}$ is heat loss by condensation calculated from the heat of vaporization of the amount of water $\left(X_{\text {cond }}\right)$ condensing on the cover (Block 4$)$.

Heat balance assuming mechanical ventilation and a heat exchanger and $P_{\text {vent }}$ in that case are based on the extra amount of moisture to be removed by dehumidification $\left(X_{\text {to remove }}\right.$, Block 5) assuming unwanted ventilation taking care of a part of the moisture, and on measured heat and moisture efficiencies of the heat exchanger. When cooling or when more moisture than the mechanical ventilation can remove is present the extra heat and moisture is taken care of by opening the vents. Output: Hourly values of supply heat demand $\left(P_{\text {supply, }} \mathrm{kW}\right)$ and thermal energy demand

Fig. 1. Schematic overview of the simulation model used in the study 
The amount of heat generated by the boiler is an output of the model and is calculated from incoming heat and heat losses. When calculating the energy balance, the model takes into account both the amount of solar radiation and the incident angles for the different greenhouse surfaces calculated using the equations provided by Duffie and Beckman (1974) and the transpiration of the greenhouse crops leading to the conversion from sensible to latent heat. Mechanisms and processes leading to the loss of heat are ventilation, heat transmission through the greenhouse cover and floor, condensation, and air-leakage through the openings in the greenhouse envelope. The effect of wind on heat loss from the greenhouse and the effect of heat being stored in and released from the greenhouse construction, the floor, the plants etc. are not incorporated in the model.

As to the moisture balance, the new model includes the contribution due to the processes of transpiration calculated according to the equations by Stanghellini (1987) and losses due to the ventilation, condensation and airleakage through the gaps in the greenhouse structure. The energy consumption for dehumidification using natural ventilation (Fig. 1) is calculated from the modelled heat balance of the greenhouse where the ventilation rate is calculated from the hourly amount of moisture to be removed $(X, \mathrm{~kg})$ and from measured indoor and outdoor humidity $\left(x, \mathrm{~kg} \mathrm{~kg}^{-1}\right)$. The amount of moisture to remove $(X)$ is calculated from the difference between transpiration of the crop, and the sum of condensation on the cover and infiltration. The amount of moisture condensing on the cover is influenced by many factors. In the model the condensation on the cover is represented by the assumption that it is proportional to heat transfer for dry air due to convection (Fig. 1).

The energy demand when using the heat exchanger is based on a heat balance where the amount of heat recovered and moisture removed are based on temperature and moisture efficiencies. When the capacity of the mechanical ventilation and the heat exchanger is too low to take care of the moisture, natural ventilation will take care of the rest.

During daytime and sunny mild weather no supply heat is used according to the heat balance calculations since the heat from the sun is enough to heat also the air flow used to remove excess moisture. In the calculations no regard has been taken to possible fogging during sunny days.

The model calculations (ventilation rates) in this study are based on the measured values of temperature and humidity in each compartment inside the greenhouse at a height of $1.8 \mathrm{~m}$ and the average values for all compartments at a specific time was used as input to the model. The model calculations thus simulate the heat balance (and heat demand) for the average indoor climate measured at that height. Differences in indoor climate due to stratification are not included in the model.

\section{Modelling and simulations}

The total use of thermal energy for the greenhouse was measured and compared with modelled data. In the greenhouse in question the dehumidification was taken care of by natural ventilation, i.e. by opening the vents to ventilate when the level of humidity was above its set-point. Thus, in the first step of modelling, values for dehumidification by ventilation were calculated. During the modelling, two values of leaf area index (LAI), i.e. 3.5 and $4.0 \mathrm{~m}^{2} \mathrm{~m}^{-2}$, were used leading to different transpiration rates of the plants and thus also to a change in demand of energy for dehumidification.

For each value of LAI, both the total use of thermal energy and the use of energy for ventilation for dehumidification (energy needed for removal of moisture by ventilation according to the modelled moisture balance, see Fig.1) were calculated for the months of April - September. Further, it was computed how much energy is used under sunlight and under no-sunlight conditions (when $\mathrm{q}_{\text {solar }} \leq 5 \mathrm{~W} \mathrm{~m}^{-2}$ ).

In the second step, the process of dehumidification by heat exchange was modelled. It was assumed that mechanical ventilation with an air-to-air rotating heat exchanger operating with the temperature and moisture efficiencies determined during the in situ measurements was incorporated into the greenhouse system.

\section{Heat exchanger and in situ measurements}

A rotating heat exchanger (Fig. 2) consists of an energy wheel and two ducts, one passing through the one half of the wheel and another one leading through the other half. One of the ducts contains the incoming outdoor air (intake) and the air supplied to the indoor space (supply) and the second one carries the air extracted from the indoor space (return) and the air exhausted to the outside (exhaust). The air-permeable energy wheel rotates 
enabling a heat and moisture exchange between the two counter-flowing streams, i.e. the intake air and the return air. A rotating heat exchanger VVVA by Swegon (Fig. 2) installed at the Swedish University of Agricultural Sciences in Alnarp was used in this study in order to estimate the potential for heat energy savings for dehumidification purposes. In these measurements both temperature efficiency and the amount of moisture transferred from the return air to the supply air was estimated. In the measurements an AAC- $2^{16}$ (Analog to ASCII Converter) PC logger was used for data recording.

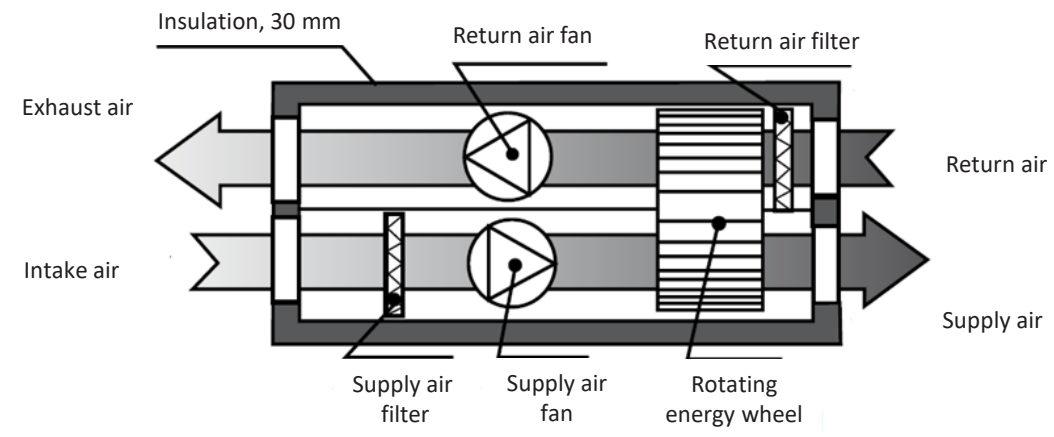

Fig. 2. Schematic design of the rotating heat exchanger used in the study (adapted from Swegon 2012)

Humidity was measured by Rotronic ${ }^{\circledR}$ Hygrometers C 94 having the accuracy of $\pm 1 \%$ RH in the range of $5 \%$ to $95 \%$ $\mathrm{RH}$ at $23{ }^{\circ} \mathrm{C}$. Prior to the actual in situ measurements for the heat exchanger, calibration of the temperature and humidity sensors used was performed. Humidity sensors were calibrated by the help of Rotronic ${ }^{\circledR}$ AG humidity standards. Air temperatures were measured by means of thermocouples (type T). The temperature of the supply air $\left(\mathrm{t}_{\text {supply }}\right)$, the temperature of the intake air $\left(\mathrm{t}_{\text {intake }}\right)$ and the temperature of the return air $\left(\mathrm{t}_{\text {return }}\right)$ were used to calculate the heat exchanger temperature efficiency $\left(\eta_{t}\right)$ according to the formula:

$$
\eta_{t}=\left(t_{\text {supply }}-t_{\text {intake }}\right) /\left(t_{\text {return }}-t_{\text {intake }}\right) \times 100 \%
$$

where $t_{\text {supply }}, t_{\text {intake }}$ and treturn $\left({ }^{\circ} \mathrm{C}\right)$ denote the temperatures of different streams of air.

For the estimation of the amount of water vapor returning, a value of moisture efficiency was calculated similarly to temperature efficiency. The values of moisture content in the supply air $\left(x_{\text {supply }}\right)$, in the intake air $\left(x_{\text {intake }}\right)$ and in the return air $\left(x_{\text {return }}\right)$ were used to compute this moisture efficiency $\left(n_{x}\right)$ in accordance with the following formula:

$$
\eta_{t}=\left(x_{\text {supply }}-x_{\text {intake }}\right) /\left(x_{\text {return }}-x_{\text {intake }}\right) \times 100 \%
$$

where $\mathrm{x}_{\text {supply }} \mathrm{x}_{\text {intake }}$ and xreturn $\left(\mathrm{kg}_{\mathrm{H}_{2} \mathrm{O}} \mathrm{kg}_{\text {air }}{ }^{-1}\right)$ are the humidity contents in different streams of air.

The obtained efficiencies were used in the model to determine how much energy can be saved thanks to the application of a heat exchanger of a certain size. In these Powersim ${ }^{\circledR}$ calculations the maximum flow rate for the heat exchanger was set to 1.5 liter air per $\mathrm{m}^{2}$ floor area and second. This value was based on older estimations of dehumidification demand in southern Sweden at times of the days when supply heat is needed (Gustafsson and Nimmermark 1991). Much of the moisture will be removed by infiltration and at parts of the day by condensation on the cover or by higher heat from the sun leading to a cooling demand and opening of the vents. In the model calculations the mechanical ventilation with heat exchanger dehumidifies the greenhouse at times when supply heat is needed, and if the capacity of the mechanical system is too low for taking care of all excess humidity the roof vents are open at the same time.

A rough estimation of the electrical energy demand and the power consumption $(P, W)$ for fans moving the air to and from the heat exchanger when using mechanical ventilation and a heat exchanger was calculated by the help of an equation for ideal power consumption for fans (without losses) expressed by the equation $P=d p^{*} q$, where $d p$ is the total pressure increase in the fan $(\mathrm{Pa})$ and $q$ is the air flow rate of the $\mathrm{fan}\left(\mathrm{m}^{3} \mathrm{~s}^{-1}\right)$. In calculations the air flow was an output of the model calculations, and the pressure increase was set to $300 \mathrm{~Pa}$ after studying 
data sheets for air handling units. The derived value was corrected for $75 \%$ efficiency of the fans. The calculated electrical energy demand for the fans was compared with the modelled savings for the system with mechanical ventilation and a heat exchanger.

\section{Results}

In the studied greenhouse, the measured average values of indoor temperature and $\mathrm{RH}$ were $19.6{ }^{\circ} \mathrm{C}$ and $81 \%$ during April to September. The temperature set-point was $21^{\circ} \mathrm{C}$ during the day and $17{ }^{\circ} \mathrm{C}$ during the night. Daily average values of outdoor temperatures in April, May, June, July, August and September were 8.2, 11.6, 16.2, 16.0, 17.2 , and $13.0^{\circ} \mathrm{C}$ respectively. Daily average values of outdoor $\mathrm{RH}$ ranged between 69 and $91 \%$ for the separate

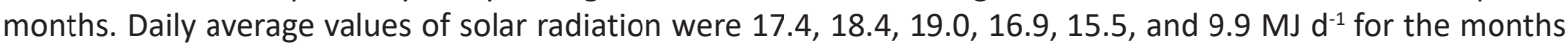
April, May, June, July, August and September respectively.

According to the measurements, the total amount of thermal energy used in the investigated greenhouse for the period of April - September was $683 \mathrm{MJ} \mathrm{m}^{-2}$. The measured use of thermal energy in April, May, June, July, August and September was 157, 130, 74, 94, 107 and $121 \mathrm{MJ} \mathrm{m}^{-2}$, correspondingly.

Based on the simulations performed with LAI $3.5 \mathrm{~m}^{2} \mathrm{~m}^{-2}$, the total use of thermal energy during April - September was $596 \mathrm{MJ} \mathrm{m}^{-2}$ When LAl was assumed to be $4.0 \mathrm{~m}^{2} \mathrm{~m}^{-2}$, the use of thermal energy for the period of April - September was calculated to $651 \mathrm{MJ} \mathrm{m}^{-2}$.

Figures 3 and 4 present the comparison between the measured and the simulated use of thermal energy in consecutive months for LAI 3.5 and $4.0 \mathrm{~m}^{2} \mathrm{~m}^{-2}$. In regressions of daily measured versus daily simulated amounts of thermal energy use $\mathrm{R}^{2}$-values were $75-76 \%$ for both LAI indexes, while $\mathrm{R}^{2}$-values in regressions based on hourly measured and simulated values were lower (approximately 30\%). Mean of diurnal variations in July of measured and simulated use of thermal energy for a leaf area index (LAI) of $4.0 \mathrm{~m}^{2} \mathrm{~m}^{-2}$ is shown in Fig 5. During this month, the mean temperatures inside the greenhouse at $0400 \mathrm{~h}, 1400 \mathrm{~h}$ and $2300 \mathrm{~h}$ were $17.3^{\circ} \mathrm{C}, 23.3^{\circ} \mathrm{C}$ and $17.4{ }^{\circ} \mathrm{C}$ respectively.

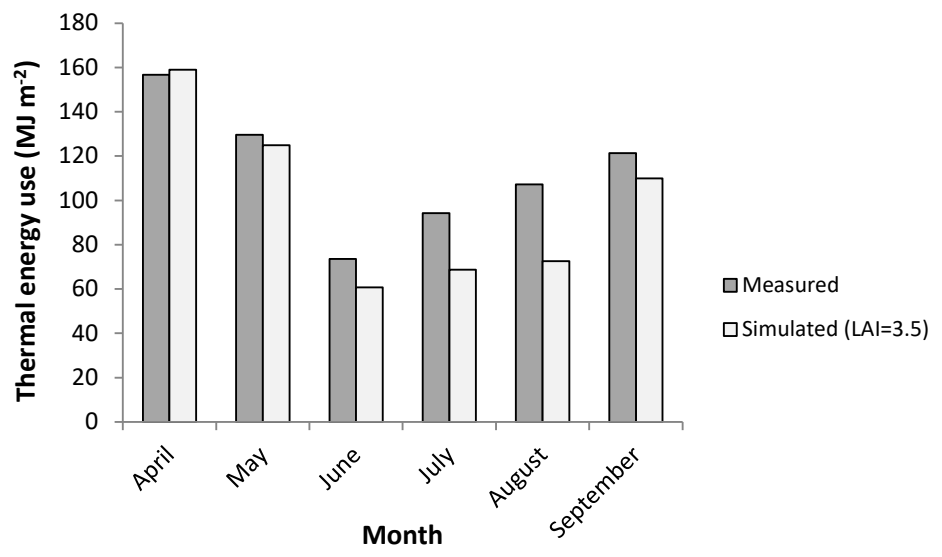

Fig. 3. Measured and simulated thermal energy use for the tomato greenhouse for the months of April - September. In simulations a leaf area index (LAI) of $3.5 \mathrm{~m}^{2} \mathrm{~m}^{-2}$ is assumed.

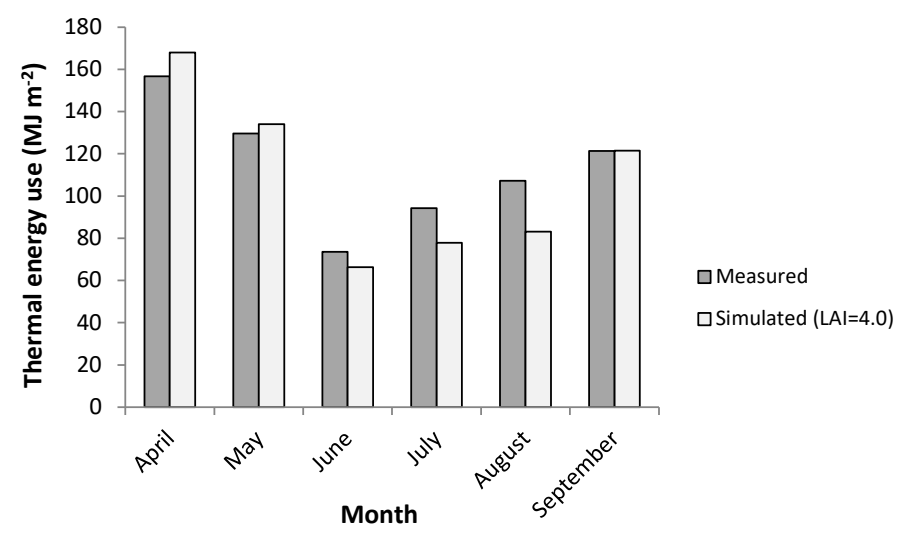

Fig. 4. Measured and simulated thermal energy use for the tomato greenhouse for the months of April - September. In simulations a leaf area index (LAI) of $4.0 \mathrm{~m}^{2} \mathrm{~m}^{-2}$ is assumed. 


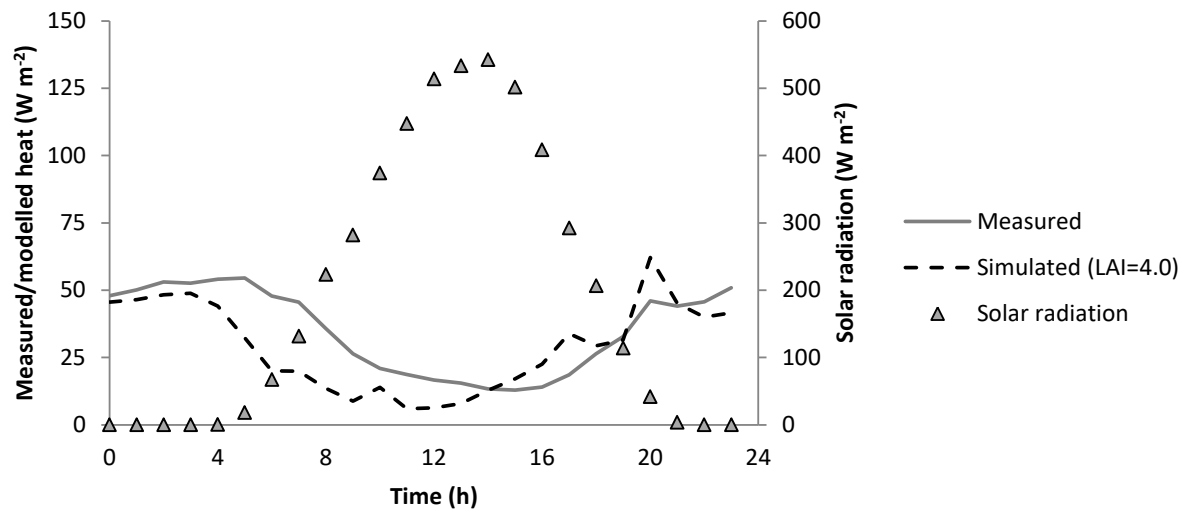

Fig. 5. Mean of diurnal variations in July of measured and simulated use of thermal energy for a leaf area index (LAI) of $4.0 \mathrm{~m}^{2} \mathrm{~m}^{-2}$

The Tables 1 and 2 show the simulated total use of thermal energy and the use for dehumidification by natural ventilation for the separate months. The simulations done for LAI $3.5 \mathrm{~m}^{2} \mathrm{~m}^{-2}$ and for LAl $4.0 \mathrm{~m}^{2} \mathrm{~m}^{-2}$ showed that $23 \%$ and $29 \%$ respectively of the thermal energy use during April - September was used for dehumidification purposes. The shares under sunlight conditions were $56-64 \%$, and $0.3-0.5 \%$ under no-sunlight conditions.

Table 1. Simulated thermal energy use for the tomato greenhouse with natural ventilation under different light conditions and an assumed leaf area index (LAl) of $3.5 \mathrm{~m}^{2} \mathrm{~m}^{-2}$

\begin{tabular}{|c|c|c|c|c|c|c|c|c|c|}
\hline \multirow[b]{2}{*}{$\begin{array}{l}\text { Light } \\
\text { conditions }\end{array}$} & \multirow[b]{2}{*}{ Use } & & \multicolumn{7}{|c|}{ Simulated thermal energy use for LAI $3.5 \mathrm{~m}^{2} \mathrm{~m}^{-2}$} \\
\hline & & & April & May & June & July & August & September & SUM \\
\hline \multirow{3}{*}{$\begin{array}{l}\text { No-sunlight } \\
\text { conditions }\end{array}$} & Total use & $\left(\mathrm{MJ} \mathrm{m}^{-2}\right)$ & 98.7 & 78.0 & 36.9 & 39.3 & 36.9 & 62.5 & 352 \\
\hline & \multirow{2}{*}{$\begin{array}{l}\text { Ventilation for } \\
\text { dehumidification }\end{array}$} & $\left(\mathrm{MJ} \mathrm{m} \mathrm{m}^{-2}\right)$ & 0.2 & 0.0 & 0.1 & 0.4 & 0.3 & 0.1 & 1.1 \\
\hline & & $(\%)^{*}$ & $<1$ & $<1$ & $<1$ & $<1$ & $<1$ & $<1$ & $<1$ \\
\hline \multirow{3}{*}{$\begin{array}{l}\text { Sunlight } \\
\text { conditions }\end{array}$} & Total use & $\left(\mathrm{MJ} \mathrm{m}^{-2}\right)$ & 60.2 & 46.9 & 23.8 & 29.4 & 35.6 & 47.4 & 243 \\
\hline & \multirow{2}{*}{$\begin{array}{l}\text { Ventilation for } \\
\text { dehumidification }\end{array}$} & $\left(\mathrm{MJ} \mathrm{m}^{-2}\right)$ & 26.1 & 22.3 & 11.9 & 18.1 & 26.4 & 30.8 & 136 \\
\hline & & $(\%)^{*}$ & 43 & 48 & 50 & 62 & 74 & 65 & 56 \\
\hline \multirow{3}{*}{$\begin{array}{l}\text { All light } \\
\text { conditions } \\
\text { (all values) }\end{array}$} & Total use & $\left(\mathrm{MJ} \mathrm{m}^{-2}\right)$ & 159.0 & 124.9 & 60.7 & 68.6 & 72.5 & 109.9 & 596 \\
\hline & \multirow{2}{*}{$\begin{array}{l}\text { Ventilation for } \\
\text { dehumidification }\end{array}$} & $\left(\mathrm{MJ} \mathrm{m}^{-2}\right)$ & 26.4 & 22.3 & 12.0 & 18.5 & 26.7 & 30.8 & 137 \\
\hline & & $(\%)^{*}$ & 17 & 18 & 20 & 27 & 37 & 28 & 23 \\
\hline
\end{tabular}

Table 2. Simulated thermal energy use for the tomato greenhouse with natural ventilation under different light conditions and an assumed leaf area index (LAl) of $4.0 \mathrm{~m}^{2} \mathrm{~m}^{-2}$

\begin{tabular}{|c|c|c|c|c|c|c|c|c|c|}
\hline \multirow[b]{2}{*}{$\begin{array}{l}\text { Light } \\
\text { conditions }\end{array}$} & \multirow[b]{2}{*}{ Use } & & \multicolumn{7}{|c|}{ Simulated thermal energy use for LAI $4.0 \mathrm{~m}^{2} \mathrm{~m}^{-2}$} \\
\hline & & & April & May & June & July & August & September & SUM \\
\hline \multirow{3}{*}{$\begin{array}{l}\text { No-sunlight } \\
\text { conditions }\end{array}$} & Total use & $\left(\mathrm{MJ} \mathrm{m} \mathrm{m}^{-2}\right)$ & 98.9 & 78.0 & 36.9 & 39.4 & 37.0 & 62.6 & 353 \\
\hline & \multirow{2}{*}{$\begin{array}{l}\text { Ventilation for } \\
\text { dehumidification }\end{array}$} & $\left(\mathrm{MJ} \mathrm{m} \mathrm{m}^{-2}\right)$ & 0.4 & 0.1 & 0.1 & 0.5 & 0.4 & 0.1 & 2 \\
\hline & & $(\%) *$ & $<1$ & $<1$ & $<1$ & $<1.5$ & $<1.5$ & $<1$ & $<1$ \\
\hline \multirow{3}{*}{$\begin{array}{l}\text { Sunlight } \\
\text { conditions }\end{array}$} & Total use & $\left(\mathrm{MJ} \mathrm{m} \mathrm{m}^{-2}\right)$ & 69.1 & 56.0 & 29.3 & 38.4 & 46.1 & 58.9 & 298 \\
\hline & \multirow{2}{*}{$\begin{array}{l}\text { Ventilation for } \\
\text { dehumidification }\end{array}$} & $\left(\mathrm{MJ} \mathrm{m} \mathrm{m}^{-2}\right)$ & 34.9 & 31.4 & 17.5 & 27.2 & 36.8 & 42.3 & 190 \\
\hline & & $(\%)^{*}$ & 51 & 56 & 60 & 71 & 80 & 72 & 64 \\
\hline \multirow{3}{*}{$\begin{array}{l}\text { All light } \\
\text { conditions } \\
\text { (all values) }\end{array}$} & Total use & $\left(\mathrm{MJ} \mathrm{m} \mathrm{m}^{-2}\right)$ & 168.0 & 134.0 & 66.2 & 77.9 & 83.2 & 121.5 & 651 \\
\hline & \multirow{2}{*}{$\begin{array}{l}\text { Ventilation for } \\
\text { dehumidification }\end{array}$} & $\left(\mathrm{MJ} \mathrm{m}^{-2}\right)$ & 35.4 & 31.5 & 17.6 & 27.7 & 37.3 & 42.4 & 192 \\
\hline & & $(\%)^{*}$ & 21 & 24 & 27 & 36 & 45 & 35 & 29 \\
\hline
\end{tabular}


For higher values of indoor humidity $(81-86 \% \mathrm{RH})$ and $20-21{ }^{\circ} \mathrm{C}$ indoor temperatures being present in a greenhouse, and colder outdoor temperatures $\left(3-5{ }^{\circ} \mathrm{C}\right)$ the measured temperature efficiency of the rotating heat exchanger was in the range of $67-71 \%$ and its moisture efficiency was $43-48 \%$.

Higher temperature efficiencies were measured for lower indoor humidity levels. For an indoor temperature of $20-21{ }^{\circ} \mathrm{C}$, a lower indoor humidity $(25-45 \% \mathrm{RH})$ and outdoor temperatures of $2-9{ }^{\circ} \mathrm{C}$ the heat exchanger had a measured temperature efficiency of $73-82 \%$.

Examples of measured temperature and moisture efficiencies plotted for every 30 seconds during a period of 20 minutes can be seen in Fig. 6 . The average outdoor temperature in this example was $3.5^{\circ} \mathrm{C}$ and the average indoor $\mathrm{RH}$ was $84 \%$.
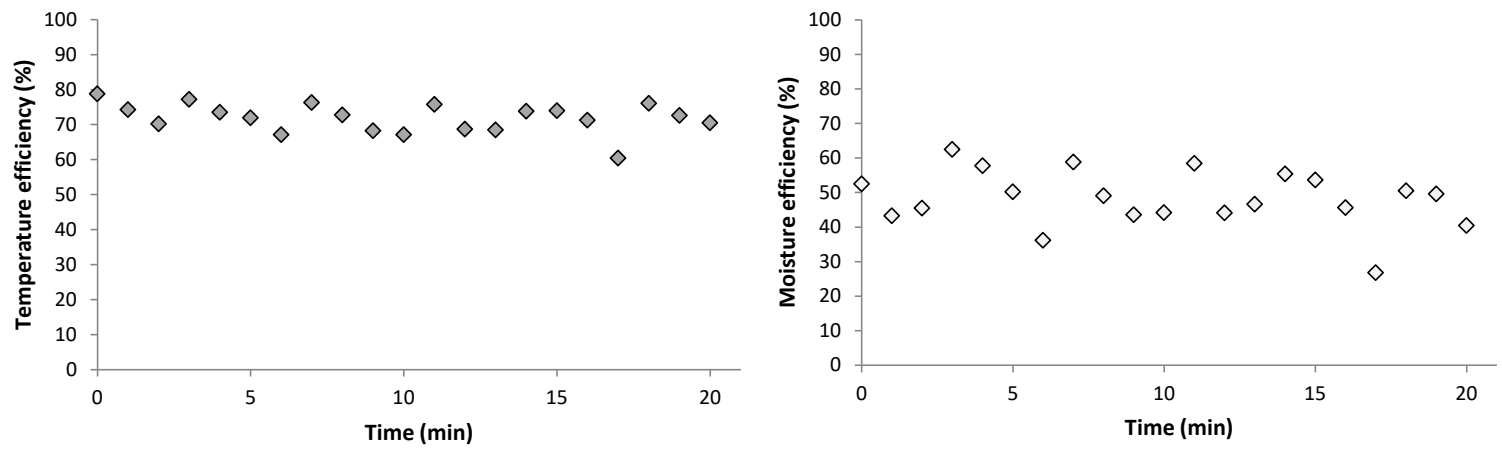

Fig. 6. Heat exchanger temperature and moisture efficiencies calculated from measurements for a period of 20 minutes

The values selected as input values for a rotating heat exchanger in simulations of the thermal energy use in the greenhouse were $70 \%$ and $45 \%$ for temperature and moisture efficiencies, respectively.

In Tables 3 and 4 simulations using mechanical ventilation and the rotating heat exchanger for dehumidification of the tomato greenhouse are shown. The simulations showed thermal energy savings of $15 \%$ (LAl $3.5 \mathrm{~m}^{2} \mathrm{~m}^{-2}$ ) and $17 \%$ ( $\mathrm{LAl} 4.0 \mathrm{~m}^{2} \mathrm{~m}^{-2}$ ) for the heat exchanger system compared to using the system with natural ventilation for dehumidification.

Table 3. Simulated thermal energy use for dehumidification of the tomato greenhouse using natural ventilation, and using a mechanical ventilation system with a heat exchanger (HEX) for an assumed leaf area index (LAI) of $3.5 \mathrm{~m}^{2} \mathrm{~m}^{-2}$

\begin{tabular}{|c|c|c|c|c|c|c|c|c|}
\hline \multirow[b]{2}{*}{$\begin{array}{l}\text { Dehumidification } \\
\text { method }\end{array}$} & & \multicolumn{7}{|c|}{ Simulated thermal energy use for LAI $3.5 \mathrm{~m}^{2} \mathrm{~m}^{-2}$} \\
\hline & & April & May & June & July & August & September & SUM \\
\hline Natural ventilation & $\left(\mathrm{MJ} \mathrm{m} \mathrm{m}^{-2}\right)$ & 159.0 & 124.9 & 60.7 & 68.6 & 72.5 & 109.9 & 596 \\
\hline $\begin{array}{l}\text { Mechanical } \\
\text { ventilation with } \\
\text { heat exchange } \\
\text { (HEX) }\end{array}$ & $\left(\mathrm{MJ} \mathrm{m}^{-2}\right)$ & 135.0 & 105.8 & 53.1 & 58.5 & 62.0 & 90.4 & 505 \\
\hline $\begin{array}{l}\text { Savings with heat } \\
\text { exchange (HEX) }\end{array}$ & (\%) & 15 & 15 & 13 & 15 & 15 & 18 & 15 \\
\hline
\end{tabular}

Table 4. Simulated thermal energy use for dehumidification of the tomato greenhouse using natural ventilation, and using a mechanical ventilation system with a heat exchanger (HEX) for an assumed leaf area index (LAI) of $4.0 \mathrm{~m}^{2} \mathrm{~m}^{-2}$

Simulated thermal energy use for LAI $4.0 \mathrm{~m}^{2} \mathrm{~m}^{-2}$

\begin{tabular}{|c|c|c|c|c|c|c|c|c|}
\hline $\begin{array}{l}\text { Dehumidification } \\
\text { method }\end{array}$ & & April & May & June & July & August & September & SUM \\
\hline Natural ventilation & $\left(\mathrm{MJ} \mathrm{m}^{-2}\right)$ & 168.0 & 134.0 & 66.2 & 77.9 & 83.2 & 121.5 & 651 \\
\hline $\begin{array}{l}\text { Mechanical } \\
\text { ventilation with } \\
\text { heat exchange } \\
\text { (HEX) }\end{array}$ & $\left(\mathrm{MJ} \mathrm{m}^{-2}\right)$ & 138.4 & 109.8 & 56.2 & 64.6 & 70.2 & 98.0 & 537 \\
\hline $\begin{array}{l}\text { Savings with heat } \\
\text { exchange (HEX) }\end{array}$ & $(\%)$ & 18 & 18 & 15 & 17 & 16 & 19 & 17 \\
\hline
\end{tabular}


For the system with mechanical ventilation and heat exchange rough estimations indicate that an extra amount of electricity of about $15 \%$ of the savings of thermal energy is needed for driving fans.

The modelled additional free ventilation through roof vents at times of the days when the capacity of the mechanical system was unable to take care of all excess humidity are shown for some days in Figure 7. In the Figure 7 ventilation through roof vents are shown at times of the days when supply heat is needed but not when cooling is needed.
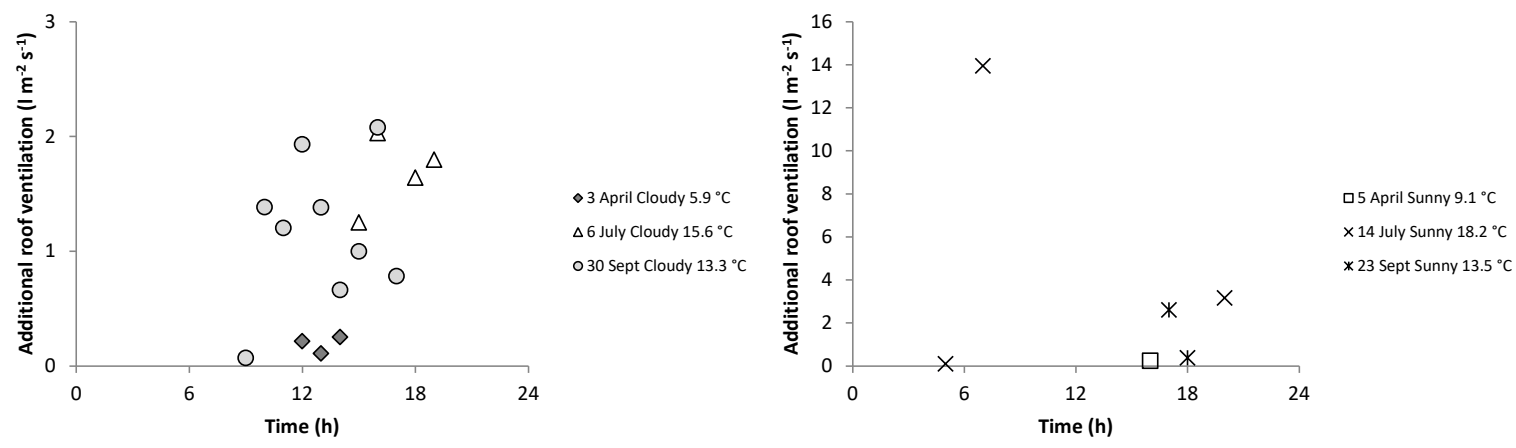

Fig. 7. Modeled additional free ventilation through roof vents for some sunny and cloudy days at times when supply heat is needed and the capacity of the mechanical ventilation system with a heat exchanger (maximum air flow rate $1.5 \mathrm{I} \mathrm{m} \mathrm{m}^{-2} \mathrm{~s}^{-1}$ ) is too low for removal of all excess humidity. Temperatures denote average temperatures of the separate days.

\section{Discussion}

In situ measurements of the ventilation rate for the greenhouse with natural ventilation would have been desirable. However, reliable measurements of air flow rates for naturally ventilated buildings are difficult to achieve (Takai et al. 2013), and no such attempts were made. The present approach using a simulation model incorporates a number of uncertainties. Diurnal variations of thermal energy use in July showed an underestimation of the model compared to measured values from about 5 am until 1 pm, and a smaller overestimation between $3 \mathrm{pm}$ to $7 \mathrm{pm}$. One reason for this is that storage and release of thermal energy are not included in the model calculations. In the mornings when the greenhouse temperature increases heat is used for warming the greenhouse construction (floor, plants, etc.) and in the evenings when the temperature decreases stored heat is released. Another likely reason for differences between modelled and measured thermal energy use is attributed to the control of the real-world greenhouse being less precise than the modelled control. The simulations for the months April September indicated that the energy necessary for the ventilation to dehumidify the greenhouse constitutes a significant share of the total thermal energy used in the greenhouse -23 and $29 \%$ when LAl was set to 3.5 and 4.0 $\mathrm{m}^{2} \mathrm{~m}^{-2}$ respectively. For both values of LAI, the simulated share of energy required for ventilation for dehumidification was highest in the months of July, August and September. In a study of a greenhouse in Canada (Quebec) it was found that proportional ventilation for dehumidification in a tomato greenhouse increased the thermal energy use on a yearly basis by $18.4 \%$ compared to no dehumidification at all (de Halleaux and Gauthier 1998). Coomans et al. (2013) concluded that the use of energy in a greenhouse can be greatly reduced when dehumidification is controlled by mechanical ventilation, and for the period of January - November, $12 \%$ of the energy used in their study was recuperated by a heat exchanger. This value is slightly lower than the savings obtained in this study. It might be due to the climate and the fact that the measurements and modelling in this study were not done for winter months when the need for dehumidification is lower.

The LAI in the greenhouse may have been somewhat different from the values used in the simulations being an estimate and they also likely varied during the year. In general, the value of LAl is conditioned by the density of tomato stems, by the number of leaves and by the size of each leaf. A higher LAl leads to higher transpiration rate and thus to an increased need for ventilation for dehumidification. The total amount of thermal energy simulated for LAl of $4.0 \mathrm{~m}^{2} \mathrm{~m}^{-2}$, i.e. $651 \mathrm{MJ} \mathrm{m}^{-2}$, is closer to the measured value of $683 \mathrm{MJ} \mathrm{m}^{-2}$ than the use simulated for LAI of $3.5 \mathrm{~m}^{2} \mathrm{~m}^{-2}$, i.e. $596 \mathrm{MJ} \mathrm{m}$. The lower use of thermal energy when LAI was set to $3.5 \mathrm{~m}^{2} \mathrm{~m}^{-2}$ may be attributed to an underestimated influence of transpiration and thus to a lower energy demand for ventilation. Keeping the LAl lower by an increased removal of leaves of the tomato plants might be an option to save energy. However, such an approach must also include considerations of how this will affect the crop yield. In studies, LAI has been shown to affect light interception and crop yield (Jones et al. 1989, Heuvelink et al. 2005). The amount of energy used for dehumidification could also be lower if the humidity set-point in a greenhouse is higher. This, however, might affect the plants in a negative way by increasing the risk of fungal diseases. 
According to the information provided by the producer of the heat exchanger used in this study, the temperature efficiency is about 78\% (Swegon 2012). The measurements performed for a lower indoor humidity showed that such a value of efficiency can be achieved. However, at higher indoor humidity levels of about $80 \% \mathrm{RH}$, the obtained temperature efficiency was lower, i.e. about $70 \%$.

In the measurements for the rotating heat exchanger at higher indoor humidity levels of about $80 \% \mathrm{RH}$, the moisture efficiency of $43-48 \%$ obtained in this study indicated that a significant amount of moisture was transferred from the return air stream to the supply air. The reason for that is the process of condensation occurring on the rotating wheel and evaporation of a part of the condensed water in the incoming air stream. For humid air of about $20{ }^{\circ} \mathrm{C}$ and $80 \% \mathrm{RH}$ or above, a decrease in temperature of just a few ${ }^{\circ} \mathrm{C}$ will lead to condensation. When rotating heat exchangers are used for ordinary buildings the indoor air in most cases have a moisture content which is just slightly higher than in the outdoor air and just a very small part of the moisture will be transferred from the return air stream to the supply air by this reason. The percentage of thermal energy that can be saved when using a heat exchanger was in the calculations slightly higher for the LAI of $4.0 \mathrm{~m}^{2} \mathrm{~m}^{-2}$, i.e. for a case with a larger contribution of transpiration to the moisture balance. De Halleaux and Gauthier (1998) concluded that the use of energy in a greenhouse using heat exchangers for dehumidification is lowered proportionally to the heat exchanger efficiency.

According to the calculations the assumed capacity of the heat exchanger $1.5 \mathrm{I} \mathrm{m}^{-2} \mathrm{~s}^{-1}$ could be a reasonable size for a tomato greenhouse in southern Sweden. Experimental studies with heat exchanger systems in greenhouses would give an improved base for choosing the size.

Without preheating, the temperature of the air returning to the greenhouse from the heat exchanger can be too low and a heater mounted in air handling units tempering the incoming air can be a good choice. In general, adding heat to the incoming air will reduce the need of heat coming from the ordinary heating system. Mixing air coming from the heat exchanger with greenhouse air is a possibility if preheating is to be avoided, but such a system working properly may be hard to design.

\section{Conclusions}

Based on the performed study, the following conclusions and concluding remarks can be made:

The simulations indicated that significant amounts of thermal energy are needed for dehumidification of a tomato greenhouse located in southern Sweden. For the studied greenhouse with natural ventilation the magnitude of thermal energy use for dehumidification was, depending on the transpiration level, estimated to $23-29 \%$ of the total use of thermal energy for climatization of the greenhouse.

The measurements performed for a rotary heat exchanger operating at higher indoor humidity levels of about $80 \% \mathrm{RH}$ at indoor temperatures of $20-21^{\circ} \mathrm{C}$ and lower outdoor temperatures showed that water vapor transferred from exhaust to supply air significantly lowered the dehumidification capacity for a specific unit.

According to the results of the modelling, the usage of mechanical ventilation and a rotary heat exchanger for dehumidification may reduce the use of thermal energy in the studied tomato greenhouse by $15-17 \%$ during the months April to September compared to dehumidification by natural ventilation and heating.

\section{Acknowledgements}

The Swedish Research Council Formas is gratefully acknowledged for funding the research.

\section{References}

Abe, O.O., Simonson, C.J., Besant, R.W. \& Shang, W. 2006. Effectiveness of energy wheels from transient measurements. Part I: Prediction of effectiveness and uncertainty. International Journal of Heat and Mass Transfer 49: 52-62. https://doi.org/10.1016/j. ijheatmasstransfer.2005.08.002

Al-Ghamdi, A.S. 2006. Analysis of air-to-air rotary energy wheels. Ph.D. Dissertation, Russ College of Engineering and Technology, Ohio University, Athens, Ohio, USA. 269 p.

Babadoost, M. 2011. Leaf mold (Fulvia fulva), a serious threat to high tunnel tomato production in Illinois. Acta Horticulturae 914: 93-96. https://doi.org/10.17660/ActaHortic.2011.914.14 
K. Maslak \& S. Nimmermark (2017) 26: 56-66

Bakker J.C. 1991. Analysis of humidity effects on growth and production of glasshouse fruit vegetables. PhD Dissertation, Agricultural University, Wageningen, The Netherlands. 155 p.

Bakker, J.C., de Zwart, H.F. \& Campen, J.B. 2006. Greenhouse cooling and heat recovery using fine wire heat exchangers in a closed pot plant greenhouse: design of an energy producing greenhouse. Acta Horticulturae 719: 263-270. https://doi.org/10.17660/ ActaHortic.2006.719.29

Campen, J.B. \& Bot, G.P.A. 2002. Dehumidification in greenhouses by condensation on finned pipes. Biosystems Engineering 82: 177-185. https://doi.org/10.1006/bioe.2002.0058

Campen, J.B., Bot, G.P.A. \& de Zwart, H.F. 2003. Dehumidification of greenhouses at northern latitudes. Biosystems Engineering 86: 487-493. https://doi.org/10.1016/j.biosystemseng.2003.08.008

Coomans, M., Allaerts, K., Wittemans, L. \& Pinxteren, D. 2013. Monitoring and energetic performance of two similar semiclosed greenhouse ventilation systems. Energy Conversion and Management 76: 128-136. https://doi.org/10.1016/j.enconman.2013.07.028

de Halleux, D. \& Gauthier, L. 1998. Energy consumption due to dehumidification of greenhouses under northern latitudes. Journal of Agricultural Engineering Research 69: 35-42. https://doi.org/10.1006/jaer.1997.0221

Dinglreiter, U. \& Mayinger, F. 1999. Enhancement of combined heat and mass transfer in rotary exchangers. In: Kakaç, S., Bergles, A.E., Mayinger, F. \& Yuncu, H. (eds.). Heat transfer enhancement of heat exchangers. Dordrecht: Kluwer Academic Publishers. p. 381-394. https://doi.org/10.1007/978-94-015-9159-1_20

Duffie, J.A. \& Beckman, W.A. 1974. Solar energy thermal processes. New York: John Wiley \& Sons, Inc. 386 p.

Enventus 2014. Rotary heat exchangers. Product catalogue. Jönköping: Enventus. 45 p.

Farooq M., Wahid, A., Kobayashi, N., Fujita, D. \& Basra, S.M.A. 2009. Plant drought stress: effects, mechanisms and management. Agronomy for Sustainable Development 29: 185-212. https://doi.org/10.1051/agro:2008021

Gustafsson, G. \& Nimmermark, S. 1991. Avfuktning med värmepump i växthus. Swedish University of Agricultural Sciences, Department of Farm Buildings (LBT), Lund, Sweden. 76 p. (in Swedish).

Heuvelink, E., Bakker, M.J., Elings, A., Kaarsemaker, R.C. \& Marcelis, L.F.M. 2005. Effect of leaf area on tomato yield. Acta Horticulturae 691: 43-50. https://doi.org/10.17660/ActaHortic.2005.691.2

Jaleel, C.A., Manivannan, P., Wahid, A., Farooq, M., Al-Juburi, H.J., Somasundaram, R. \& Panneerselvam, R.P. 2009. Drought stress in plants: A review on morphological characteristics and pigments composition. International Journal of Agriculture and Biology 11: 100-105.

Jones, J.W., Dayan, E., Van Keulen, H. \& Challa, H. 1989. Modelling tomato growth for optimizing greenhouse temperatures and carbon dioxide concentrations. Acta Horticulturae 248: 285-294. https://doi.org/10.17660/ActaHortic.1989.248.34

Kakaç, S., Liu, H. \& Pramuanjaroenkij, A. 2012. Heat Exchangers: Selection, Rating, and Thermal Design. Third edition. Boca Raton, FL: CRC Press. $631 \mathrm{p}$.

Kittas, C., Katsoulas, N. \& Bartzanas, T. 2012. Greenhouse climate control in Mediterranean greenhouses. Cuadernos de Estudios Agroalimentarios (CEA) 3: 89-114.

Longo, G.A. \& Gasparella, A. 2012. Comparative experimental analysis and modelling of a flower greenhouse equipped with a desiccant system. Applied Thermal Engineering 47: 54-62. https://doi.org/10.1016/j.applthermaleng.2012.03.008

Mardiana-Idayu, A. \& Riffat, S.B. 2012. Review on heat recovery technologies for building applications. Renewable and Sustainable Energy Reviews 16: 1241-1255. https://doi.org/10.1016/j.rser.2011.09.026

Migeon, C., Pierart, A., Lemesle, D., Travers, A. \& Chassériaux, G. 2012. A dehumidifying heat pump for greenhouses. Acta Horticulturae 952: 485-492. https://doi.org/10.17660/ActaHortic.2012.952.61

Nilsson, G. 1985. Manual till datorprogrammet EBBE. Swedish University of Agricultural Sciences, Department of Farm Buildings (LBT), Lund, Sweden. 36 p. (in Swedish).

Pollet, I.V. \& Pieters, J.G. 2000. Condensation and radiation transmittance of greenhouse cladding materials, Part 3: Results for glass plates and plastic films. Journal of Agricultural Engineering Research 77: 419-428. https://doi.org/10.1006/jaer.2000.0628

Rousse, D.R., Martin, D.Y., Theriault, R., Léveillée, F. \& Boily, R. 2000. Heat recovery in greenhouses: a practical solution. Applied Thermal Engineering 20: 687-706. https://doi.org/10.1016/S1359-4311(99)00048-4

Simonson, C.J. \& Besant, R.W. 1999. Energy wheel effectiveness: part I-development of dimensionless groups. International Journal of Heat and Mass Transfer 42: 2161-2170. https://doi.org/10.1016/S0017-9310(98)00325-1

Sparrow, E.M., Tong, J.C.K., Johnson, M.R. \& Martin, G.P. 2007. Heat and mass transfer characteristics of a rotating regenerative total energy wheel. International Journal of Heat and Mass Transfer 50: 1631-1636. https://doi.org/10.1016/j.ijheatmasstransfer.2006.07.035

Stanghellini, C. 1987. Transpiration of greenhouse crops: an aid to climate management. PhD thesis. Wageningen University, Wageningen, The Netherlands. $150 \mathrm{p}$.

Swegon. 2012. Värmeåtervinningsaggregat VVVA. Göteborg: Swegon: p. 167-172. (in Swedish).

Takai, H., Nimmermark, S., Banhazi, T., Norton, T., Jacobson, L.D., Calvet, S., Hassouna, M., Bjerg, B., Zhang, G.-Q., Pedersen, S., Kai, P., Wang, K. \& Berckmans, D. 2013. Airborne pollutant emissions from naturally ventilated buildings: Proposed research directions. Biosystems Engineering 116: 214-220. https://doi.org/10.1016/j.biosystemseng.2012.12.015

Vallières, M., de Halleux, D., Dorais, M. \& Bouzid, S. 2014. Comparison of two cooling and dehumidifying methods for a semiclosed organic tomato greenhouse. Acta Horticulturae 1037: 611-616. https://doi.org/10.17660/ActaHortic.2014.1037.78

Williamson, B., Duncan, G.H., Harrison, J.G., Harding, L.A., Elad, Y. \& Zimand, G. 1995. Effect of humidity on infection of rose petals by dry-inoculated conidia of Botrytis cinerea. Mycological Research 99: 1303-1310. https://doi.org/10.1016/S0953-7562(09)81212-4 